\title{
Iatrogenic hypothyroidism in a hyperthyroid cat treated with ${ }^{131} \mathbf{I}$
}

\author{
Iatrogene hypothyrö̈die bij een hyperthyrö̈de kat behandeld met ${ }^{131} I$
}

\author{
${ }^{1}$ N. De Laet, ${ }^{1}$ L. Stammeleer, ${ }^{2}$ E. Vandermeulen, ${ }^{1}$ D. Paepe, ${ }^{1}$ S. Daminet
}
${ }^{1}$ Small Animal Department, Faculty of Veterinary Medicine, Ghent University, Salisburylaan 133, 9820 Merelbeke, Belgium
${ }^{2}$ Department of Medical Imaging of Domestic Animals and Orthopedics of Small Animals, Faculty of Veterinary Medicine, Ghent University, Salisburylaan 133, 9820 Merelbeke, Belgium

nikita.delaet@ugent.be

\begin{abstract}
$\Lambda_{\text {bstract }}$
A thirteen-year-old, male, castrated, non-azotemic European Shorthair was presented for treatment of hyperthyroidism. Thyroid scintigraphy using $\mathrm{Tc}^{99 \mathrm{~m}}$ showed bilaterally enlarged thyroid glands with an increased thyroid to salivary $(\mathrm{T} / \mathrm{S})$ ratio. The cat was treated with an intravenous injection of $4.84 \mathrm{mCi}(179 \mathrm{MBa}){ }^{131} \mathrm{I}$. One year later, the cat showed clinical deterioration, including lethargy, weight loss and a louder heart murmur; iatrogenic hypothyroidism was diagnosed. Concurrently, renal parameters were elevated compared to the pre-treatment values. Supplementation with levothyroxine was started. Four months later, the cat was euthyroid and improved creatinine values were noted. In this case report, the diagnosis and management of iatrogenic hypothyroidism in cats and the interplay with renal function are described. An algorithm with recommendations regarding diagnosis, monitoring and treatment of these cats is presented.
\end{abstract}

\section{SAMENVATTING}

Een mannelijke, gecastreerde, niet-azotemische Europese korthaar van dertien jaar werd aangeboden voor de behandeling van hyperthyroïdie. Schildklierscintigrafie met $\mathrm{Tc}^{99 \mathrm{~m}}$ onthulde bilateraal vergrote schildklieren met een toegenomen "thyroid to salivary (T/S) ratio". De kat werd behandeld met 4,84mCi (179Mba) ${ }^{131} \mathrm{I}$. Een jaar later vertoonde de kat klinische achteruitgang, zoals lethargie, gewichtsverlies en een luidere hartruis; iatrogene hypothyroïdie werd gediagnosticeerd. Tegelijkertijd waren de nierwaarden gestegen ten opzichte van voor de behandeling. Een levothyroxinetherapie werd opgestart. Vier maanden later was de kat opnieuw euthyroïde en was de serum-creatininewaarde opnieuw gedaald. In deze casuïstiek worden de diagnostiek en het management beschreven van katten met iatrogene hypothyroïdie en het effect van iatrogene hypothyroïdie op de nierfunctie wordt nader toegelicht. Bijkomend wordt een algoritme opgesteld met aanbevelingen voor diagnostiek, monitoring en behandeling van hyperthyroïde katten die behandeld worden met radioactief jodium.

\section{INTRODUCTION}

Hyperthyroidism is the most common endocrine disorder in elderly cats (Peterson and Ward, 2007). This disease can be treated pharmacologically, surgically, dietary or with radioiodine therapy (Daminet et al., 2014) (Table 1).

Treatment with ${ }^{131} \mathrm{I}$ is considered the gold standard in many cats as it is curative and safe. The adminis- tered radioiodine is taken up by the thyroid glands and the emitted $\beta$ radiation destroys the nearby abnormal thyroid tissue. The remaining thyroid tissue is mostly atrophied, hence will be spared of most of the radiation (Daminet et al., 2014; Daminet and Hill, 2017). ${ }^{131}$ I treatment has a 90-95\% success rate (Volckaert et al., 2016). The major disadvantages of ${ }^{131} \mathrm{I}$ therapy are the need for a licenced, specialized center, the use of radioactive products, the need for hospitalization and 
Table 1. Summary of considerations regarding treatment options for feline hyperthyroidism. (Adapted from Daminet, 2019).

\begin{tabular}{|c|c|c|c|c|}
\hline & $\begin{array}{l}\text { Anti-thyroid } \\
\text { drugs }\end{array}$ & $\begin{array}{l}\text { Restricted } \\
\text { iodine diet }\end{array}$ & Thyroidectomy & ${ }^{131} \mathbf{I}$ \\
\hline Initial cost & + & + & +++ & +++ \\
\hline Long-term cost & ++ & ++ & + & + \\
\hline Pre-requisites & None & $\begin{array}{l}\text { Strict administration } \\
\text { of this diet needs } \\
\text { to be possible }\end{array}$ & $\begin{array}{l}\text { Skilled } \\
\text { surgeon }\end{array}$ & Licenced facility \\
\hline Ease of use for the owner & $\begin{array}{l}\text { Easy to } \\
\text { moderate }\end{array}$ & Easy & $\begin{array}{c}\text { Easy after } \\
\text { hospitalization }\end{array}$ & $\begin{array}{c}\text { Radioprotective } \\
\text { measures needed, } \\
\text { afterwards easy }\end{array}$ \\
\hline Need for anesthesia & No & No & Always & Sometimes \\
\hline Time to euthyroid & 2-4 weeks & $6-8$ weeks & $1-2$ days & Days to weeks \\
\hline Hospitalization & No & No & 1-3 days & 3 days to 4 weeks \\
\hline Potential limitation & $\begin{array}{l}\text { Mild side-effects } \\
\text { common }\end{array}$ & $\begin{array}{l}\text { Low palatability } \\
\text { in some cats }\end{array}$ & $\begin{array}{l}\text { Recurrence after } \\
\text { unilateral/ } \\
\text { incomplete } \\
\text { thyroidectomy }\end{array}$ & $\begin{array}{c}\text { Iatrogenic } \\
\text { hypothyroidism } \\
\text { or persistent } \\
\text { hyperthyroidism } \\
\text { possible }\end{array}$ \\
\hline
\end{tabular}

the possible development of iatrogenic hypothyroidism (Table 1).

Iatrogenic hypothyroidism has been reported in $3-79 \%$ of all ${ }^{131}$ I-treated cats, although in most studies, a prevalence of iatrogenic hypothyroidism of approximately $10 \%$ has been shown (Meric and Rubin, 1990; Boag et al., 2007; Lucy et al., 2017; Peterson et al., 2017).

Cats with iatrogenic hypothyroidism rarely show obvious clinical signs. Lethargy, weight gain and anorexia are the most commonly noted. However, these clinical signs are difficult to recognize by the owner since resolution of hyperthyroidism should lead to improvement of the typical clinical signs of hyperthyroidism, including hyperactivity, polyphagia and weight loss. The combination of these vague clinical signs and the possible influence of concurrent illness on total thyroxine (TT4) concentrations (euthyroid sick syndrome) makes diagnosing iatrogenic hypothyroidism after ${ }^{131} \mathrm{I}$ treatment challenging (Peterson, 2016).

Once iatrogenic hypothyroidism has been diagnosed, the veterinarian can decide to either start treating the cat with thyroid hormone supplementation or continue monitoring. This decision can be difficult to make and depends on a combination of the presence or absence of clinical signs, the time of diagnosis and the renal values of the cat (Williams et al., 2014).

Once treatment with levothyroxine has been initiated, frequent re-evaluations should take place to evaluate the clinical response and to measure posttreatment TT4 for therapeutic monitoring. This is important to avoid under- or overdosing of levothyroxine, with persistent hypothyroidism or iatrogenic hyperthyroidism as a consequence. Therapeutic monitoring of total T4 concentrations should take place in every cat treated with levothyroxine, because many factors, including gastrointestinal disease and concurrent administrations of other medications, influence the absorption of levothyroxine (Daminet, 2016).

In this case report, the recommended protocols of diagnosing, treating and re-evaluating iatrogenic hypothyroid cats after radioiodine treatment are described.

\section{CASE DESCRIPTION}

A thirteen-year-old, male, castrated European Shorthair was presented at the referring veterinarian with chronic weight loss, polyphagia and being quieter. The diagnosis of hyperthyroidism was confirmed based on increased serum TT4 concentration. Treatment with methimazole was instituted, and the cat was referred to the Small Animal Clinic of the Faculty of Veterinary Medicine, Ghent University, for further work-up and possibly radioiodine treatment. Blood examination (including free T4 (fT4), TT4, hematology and biochemistry), urinalysis, thoracic X-rays, echocardiography and an abdominal ultrasound were 


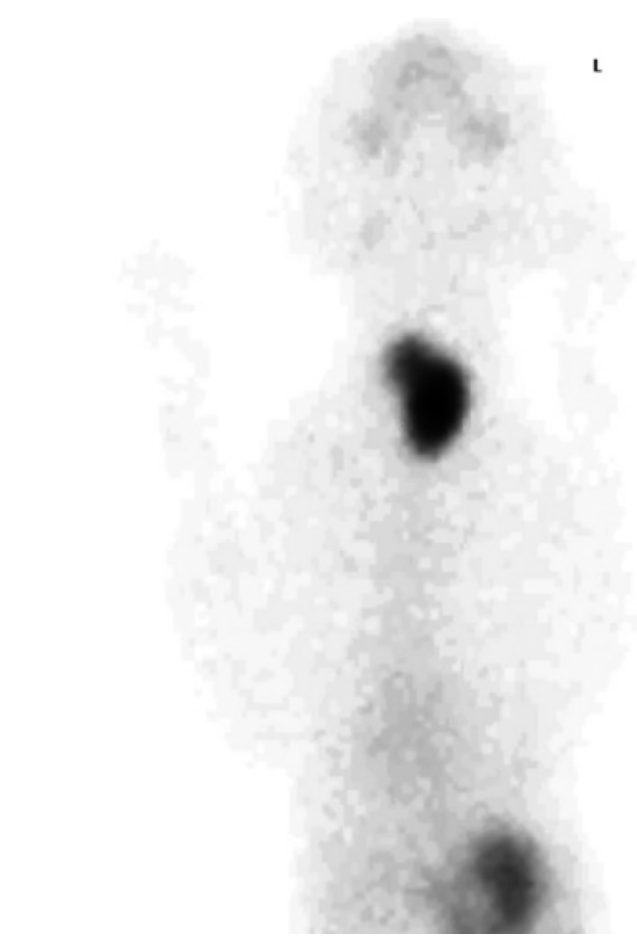

Figure 1. Pertechnetate scan in a hyperthyroid cat prior to ${ }^{131}$ I treatment.

performed as part of an extensive work-up for a prospective study.

Initial physical examination revealed typical clinical features of hyperthyroidism including muscle atrophy, palpation of a goitre and a systolic heart murmur (Table 2).

Initial blood examination, including biochemistry, hematology and thyroid profile, confirmed the diagnosis of hyperthyroidism with severely increased TT4 and fT4 values and a low normal TSH concentration (Table 3).

Urinalysis prior to the ${ }^{131}$ I treatment revealed concentrated urine with mild proteinuria (Table 4). Chest $\mathrm{X}$-rays revealed mild cardiomegaly. Echocardiography visualized mild hypertrophy of the left ventricle with borderline left atrium dilation and dynamic right ventricular outflow tract obstruction (DRVOTO). Abdominal ultrasound did not reveal any significant $a b-$ normalities.
Thyroid scintigraphy with Tc-99m showed bilateral enlarged thyroid glands with an increased tracer uptake (Figure 1). The left thyroid gland was displaced caudally. The thyroid-to-salivary $(\mathrm{T} / \mathrm{S})$ ratio was increased in both left (10/1) and right (3.9/1) thyroid glands.

The results obtained from bloodwork and pertechnetate scan in this cat were consistent with the confirmed hyperthyroidism. Treatment with an intravenous injection of $4.84 \mathrm{mCi}(179 \mathrm{MBq}){ }^{131} \mathrm{I}$ was instituted. This dose was based on the $\mathrm{T} / \mathrm{S}$ ratio obtained via scintigraphy, TT4 value and clinical signs (Volckaert et al., 2016). The cat was hospitalized for five days due to radioprotective precautions.

One month post-treatment control included urinalysis, abdominal ultrasound and echocardiography. Significant clinical improvement was noticed (Table 2). Bloodwork revealed TT4 and fT4 serum concentrations that had dropped below the reference interval and serum TSH concentration well within the upper range of the reference interval. The serum creatinine and urea concentrations were still within reference interval, but had significantly increased compared to the pre-treatment serum concentrations (Table 3 ). Urinalysis revealed decreased urine concentration compared to the baseline values (Table 4).

The patient returned for a control visit one year after treatment. Blood and urine examinations, scintigraphy, abdominal ultrasound and echocardiography were performed. Significant clinical deterioration including weight loss, mild muscle wastage and a louder heart murmur was noticed and the cat had become significantly more quiet at home (Table 2). The patient was also hypertensive with a mean blood pressure of $205 \mathrm{mmHg}$ (measured with Doppler ultrasonography).

Control bloodwork showed low normal serum TT4 and decreased serum fT4 values, combined with a high serum TSH concentration (Table 3 ). Concurrent renal disease was also suspected based on an increase in serum values of SDMA, urea and creatinine compared to pre-treatment and significant proteinuria (Tables 3 and 4). The rest of the performed bloodwork, including full hematology, biochemistry and electrolytes, was unremarkable.

Both thyroid glands could no longer be clearly

Table 2. Findings on physical examination in a hyperthyroid cat prior to ${ }^{131} \mathrm{I}$, and at one and twelve months later (T0, $\mathrm{T} 1$ and $\mathrm{T} 12$, respectively).

\begin{tabular}{lccc}
\hline & T0 & T1 & T12 \\
\hline Muscle condition score & Moderate muscle atrophy & No muscle atrophy & Mild muscle atrophy \\
Weight $(\mathrm{kg})$ & 2.8 & 3.6 & 3.02 \\
Thyroid gland palpation* & $5 / 6 \mathrm{~L}-0 / 6 \mathrm{R}$ & $4 / 6 \mathrm{~L}-0 / 6 \mathrm{R}$ & $0 / 6 \mathrm{~L}-0 / 6 \mathrm{R}$ \\
Body condition score (BCS) & $4 / 9$ & $5 / 9$ & $4 / 9$ \\
Heart murmur & $3 / 6$ & $1-2 / 6$ & $3 / 6$ \\
\hline
\end{tabular}

*Thyroid gland scoring system: score $0=$ non-palpable thyroid gland; score $1=1-3 \mathrm{~mm}$; score $2=3-5 \mathrm{~mm}$; score $3=5-8$ $\mathrm{mm}$; score $4=8-12 \mathrm{~mm}$; score $5=12-25 \mathrm{~mm}$ and score $6=\geq 25 \mathrm{~mm}$ (Boretti et al., 2005; Paepe et al., 2008). 
delineated due to decreased radionuclide uptake on thyroid scintigraphy (Figure 2). The $\mathrm{T} / \mathrm{S}$ ratio was estimated to be $0.78 / 1$, but was hard to determine due to the limited visibility of the thyroid glands on scintigraphy.

Based on the low normal TT4, low fT4, increased TSH concentration and decreased radionuclide uptake on scintigraphy, this cat was diagnosed with iatrogenic hypothyroidism one year after ${ }^{131} \mathrm{I}$ treatment.

Echocardiography showed a mild, focal thickening of the septum with very mild dilation of the left atrium. These findings did not have any clinically relevance at that time point. Abdominal ultrasound didn't show any significant abnormalities.

Supplementation with levothyroxine (Leventa MSD animal health, United Kingdom; 0,075ml $=0.075 \mathrm{mg}$ twice daily) was prescribed.

Control bloodwork was performed four months after the initiation of thyroxine supplementation. The serum TT4 concentration was within normal limits and the urea and creatinine values were mildly decreased. The cat had improved clinically. However, the serum SDMA concentrations were further increased (Table 3 ).

\section{DISCUSSION}

Although radioiodine treatment is the preferred treatment option for hyperthyroidism, in some cats, it also involves disadvantages and complications. One of the main complications is the potential development of iatrogenic hypothyroidism (Meric and Rubin,

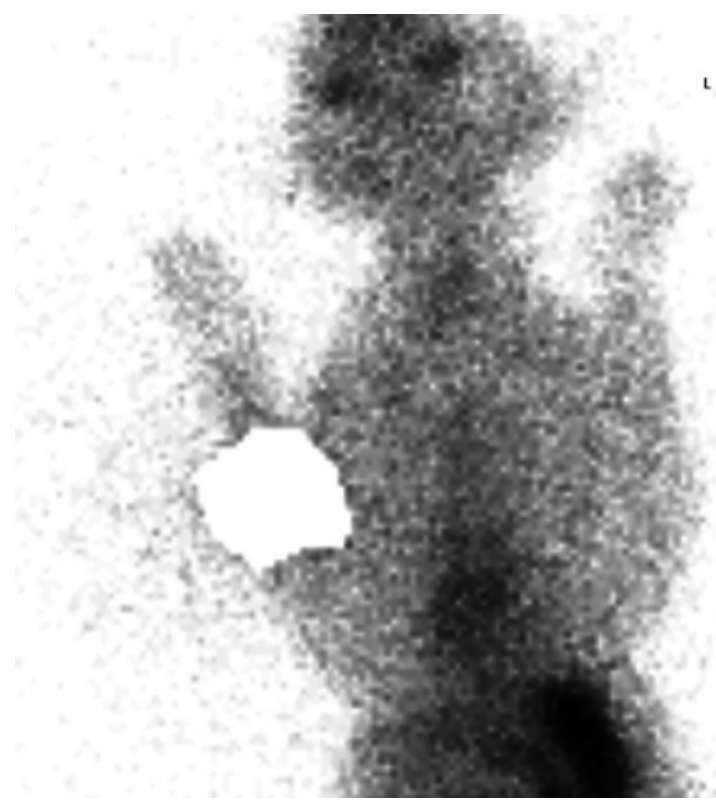

Figure 2. Pertechnetate scan in an iatrogenic hypothyroid cat, twelve months after ${ }^{131}$ I treatment to treat hyperthyroidism.

1990; Boag et al., 2007; Lucy et al., 2017; Peterson et al. 2017).

One of the predisposing factors for ${ }^{131}$ I therapy induced iatrogenic hypothyroidism is the usage of (too) high doses of radioiodine. The standard dose for treating hyperthyroidism in cats with ${ }^{131}$ I used to be approximately $4-5 \mathrm{mCi}$, but recently, it has been shown that with a dose of $2 \mathrm{mCi}$, most cats with mild-tomoderate hyperthyroidism without an increased frequency of persistent hyperthyroidism three and six

Table 3. Findings on serum biochemistry in a hyperthyroid cat prior to ${ }^{131} \mathrm{I}$, and at one, twelve and sixteen months after treatment (T0, T1, T12 and T16, respectively).

\begin{tabular}{|c|c|c|c|c|c|}
\hline & $\begin{array}{c}\text { Results } \\
\text { T0 }\end{array}$ & $\begin{array}{c}\text { Results } \\
\text { T1 }\end{array}$ & $\begin{array}{c}\text { Results } \\
\text { T12 }\end{array}$ & $\begin{array}{c}\text { Results } \\
\text { T16 }\end{array}$ & $\begin{array}{c}\text { Reference } \\
\text { interval }\end{array}$ \\
\hline Total T4 & $>167.3$ & 9 & 15.4 & 33.54 & $10-60 \mathrm{nmol} / \mathrm{l}$ \\
\hline Free T4 (Immulite) & 77.2 & 4.5 & 4.2 & & $9.0-33.5 \mathrm{pmol} / 1$ \\
\hline Free T4 (Equilibrium dialysis) & 108.7 & 5 & 11.2 & & $9.0-33.5 \mathrm{pmol} / 1$ \\
\hline TSH & 0.03 & 0.11 & 0.58 & & $0.03-0.3 \mathrm{ng} / \mathrm{ml} *$ \\
\hline Urea & 6.2 & 11.7 & 12.4 & 10.16 & $5.7-13.5 \mathrm{nmol} / 1$ \\
\hline Creatinine & 48 & 103 & 123 & 106.1 & $<168 \mu \mathrm{mol} / 1$ \\
\hline SDMA & 9 & 9 & 17 & 20 & $0-14 \mu \mathrm{g} / \mathrm{dl}$ \\
\hline Bilirubin & 1.7 & 2,7 & 2.7 & & $<6.8 \mu \mathrm{mol} / 1$ \\
\hline ALT & 277 & 150 & 129 & & $<175 \mathrm{U} / 1$ \\
\hline ALP & 155 & 46 & 36 & & $<73 \mathrm{U} / 1$ \\
\hline GGT & $<1$ & 1 & 1 & & $<5 \mathrm{U} / 1$ \\
\hline AST & 131 & 60 & 48 & & $<71 \mathrm{U} / 1$ \\
\hline Total Calcium & 2.3 & 2.5 & 2.3 & & $2,2-2,9 \mathrm{mmol} / \mathrm{L}$ \\
\hline Total Protein & 59 & & 78 & & $59-87 \mathrm{~g} / 1$ \\
\hline Albumin & 25 & & 30 & & $27-44 \mathrm{~g} / 1$ \\
\hline Globulin & 34 & & 48 & & $29-54 \mathrm{~g} / 1$ \\
\hline
\end{tabular}

SDMA = Symmetric dimethylarginine; ALT = Alanine aminotransferase $;$ ALP = Alkaline phosphatase GGT = gamma glutamyl transferase; AST = aspartate aminotransferase

*Based on Lucy et al. (2017). 
Table 4. Findings on urinalysis in a hyperthyroid cat prior to ${ }^{131} \mathrm{I}$, and at one and twelve months after treatment (T0, $\mathrm{T} 1$ and $\mathrm{T} 12$, respectively).

\begin{tabular}{ccccc}
\hline & Result T0 & Result T1 & Result T12 & Reference interval \\
\hline Specific gravity & $>1.050$ & 1.015 & 1.020 & $0-0.4$ \\
UPC & 0.6 & 0.2 & 2.9 & 0.9 \\
\hline
\end{tabular}

$\mathrm{UPC}=$ urine protein:creatinine ratio

months post therapy can be successfully treated (Lucy et al., 2017). Although the dosage currently used in the clinic at the Faculty of Veterinary Medicine (Ghent University) has been adapted to $2 \mathrm{mCi}$, the cat in the present case, treated in November 2016, still received $4.84 \mathrm{mCi}^{131} \mathrm{I}$, which is nowadays considered to be a high dose. Another predisposing factor for iatrogenic hypothyroidism is the presence of bilateral ${ }^{131}$ I uptake on thyroid scintigraphy. These cats, including the cat in the present case report, are twice as likely to develop iatrogenic hypothyroidism compared to cats with only unilateral thyroid pertechnetate uptake (Nykamp et al., 2005).

Follow-up of the clinical status and bloodwork after radioiodine treatment is of great importance to be able to make an early diagnosis of iatrogenic hypothyroidism. However, a complete work-up for iatrogenic hypothyroidism in non-azotemic cats is not recommended until three to six months post-treatment, because cats treated with ${ }^{131} \mathrm{I}$ can become transient hypothyroid. These cats regain a normal thyroid function within three to six months after treatment (Peterson et al., 2017). Considering that the cat in the present case was hypothyroid one year post-treatment, chances were very low that he would become spontaneously euthyroid again. Azotemic cats that have been treated with ${ }^{131} \mathrm{I}$, should be monitored more closely, because treatment for hyperthyroidism, development of iatrogenic hypothyroidism and potential concurrent CKD all decrease the glomerular filtration rate (GFR). Iatrogenic hypothyroidism should be diagnosed and treated as early as possible, since it improves renal function and provides a longer median survival time in these cats (Williams et al., 2014; Peterson et al., 2017).

The diagnosis of iatrogenic hypothyroidism is currently based on the measurement of serum TT4 and TSH concentrations. Elderly, euthyroid cats often have low TT4 concentrations due to concurrent nonthyroid illnesses (Peterson, 2016). Free T4 concentrations are less influenced by non-thyroidal illness and are therefore considered to be more sensitive for diagnosing iatrogenic hypothyroidism. However, the assays available for the measurement of fT 4 concentrations have a variable performance and accuracy. Determining fT4 after equilibrium dialysis (FT4ED) is considered the gold standard. However, FT4ED is an expensive and time-consuming test that is not widely available. In a recent study by Stammeleer et al. (2018), the measurement of fT4 via a chemiluminiscent enzyme immunoassay (FT4CEIA) has shown correlating, but consistently lower results compared to FT4ED. However, approximately $75 \%$ of iatrogenic hypothyroid cats have fT4 values within reference interval (Peterson et al., 2017). Therefore, it is recommended to interpret serum TT4 results in combination with serum TSH concentrations (Peterson et al., 2017).

Currently, there is no feline TSH assay available. The immulite canine TSH assay (Diagnostic Products Corporation, DPC), a chemiluminescent immunometric assay, is being used to determine TSH concentrations in cats because of the cross-reaction of this assay with feline TSH. Multiple studies have been performed to determine a reference interval (RI) for TSH in healthy, elderly cats. The suggested upper reference limit of feline TSH determined by the cTSH assay varies between $0.15 \mathrm{ng} / \mathrm{ml}$ and $0.3 \mathrm{ng} / \mathrm{ml}$ (Wakeling, 2010; Williams et al., 2010; Lucy et al., 2017). However, the choice between these two cutoff values will have a major influence on the amount of iatrogenic hypothyroid cats that will be diagnosed after ${ }^{131} \mathrm{I}$ treatment. This emphasizes the need of further studies to determine the most appropriate cut-off value for this assay in order to be able to diagnose iatrogenic hypothyroidism in cats. In addition, a recent study from Stammeleer et al. (2019) showed that approximately $27 \%$ of cats with high cTSH concentrations are euthyroid based on scintigraphy. In that study, TT4 concentrations were within the reference interval in all of these euthyroid cats with increased cTSH concentrations, which shows us the need to interpret TT4 and TSH concentrations together and with caution.

A TSH stimulation test using recombinant human TSH (rhTSH) can also be used to assess the thyroid function. Serum samples should be collected before and 6 hours after IV administration of the exogenous rhTSH. A study by Van Hoek et al. (2010) showed that iatrogenic hypothyroid cats do not show a significant increase in TT4 after the administration of rhTSH, in contrast to healthy cats or cats with non-thyroid illness. One of the main disadvantages of this test is the high cost for a vial of rhTSH. However, once opened, these vials can be stored for four to eight weeks without any loss of biological activity, making it possible to perform multiple TSH stimulation tests with one vial (De Roover et al., 2006). 


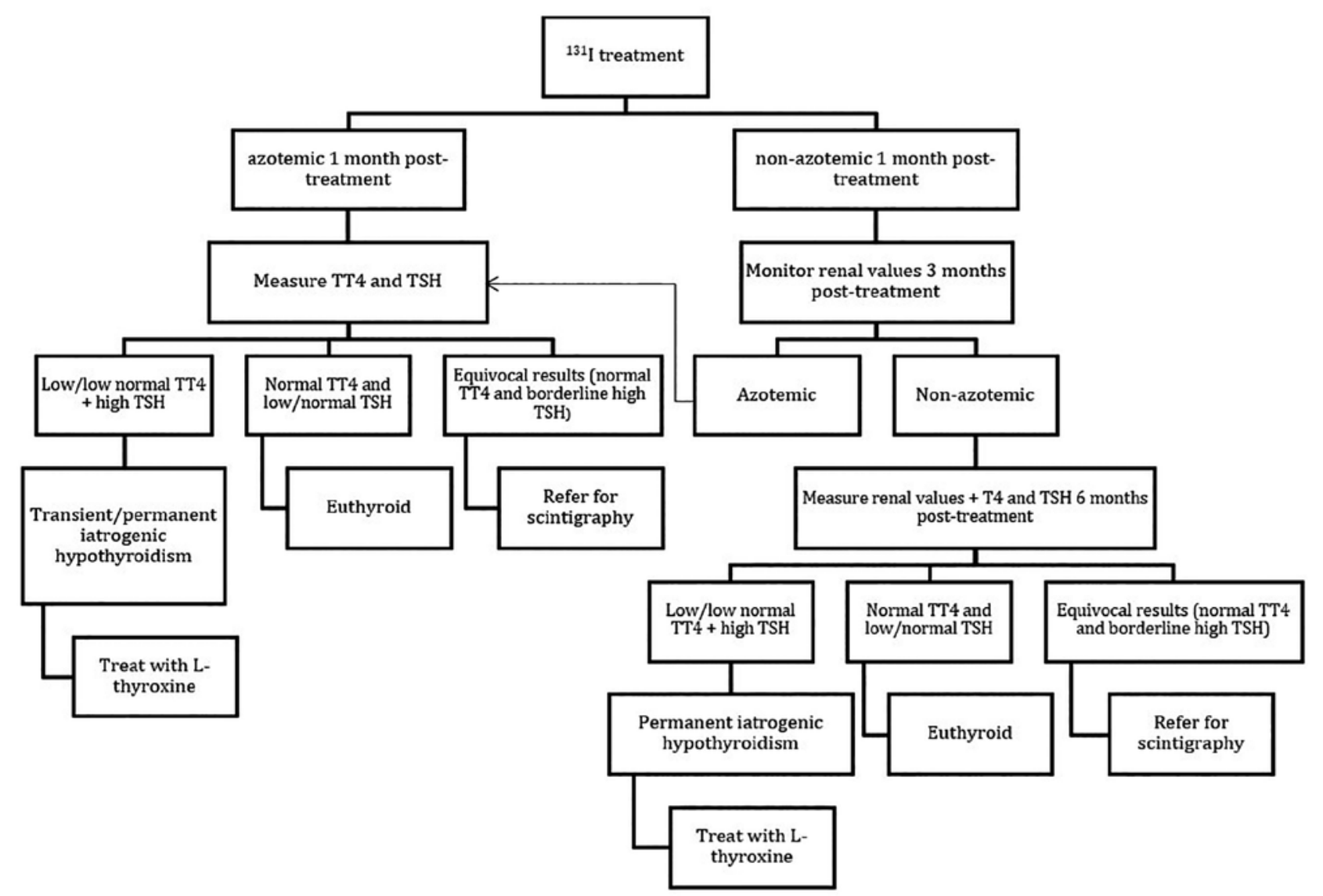

Figure 3. Algorithm with recommendations regarding the diagnosis, monitoring and treatment for cats treated with ${ }^{131}$ I (Adapted from Daminet S., 2016).

Thyroid scintigraphy is considered the best imaging modality to diagnose iatrogenic hypothyroidism in cats that had received radioiodine treatment. Cats with true iatrogenic hypothyroidism show decreased or absent radionuclide uptake on scintigraphy, whereas cats with low T4 concentrations due to non-thyroidal illness have a normal radionuclide uptake (Peterson, 2013). However, cats that become hypothyroid after methimazole treatment should not be diagnosed with scintigraphy since methimazole can potentially increase the radionuclide uptake, causing a falsely increased T/S ratio (Peterson and Broome, 2015). Unfortunately, thyroid scintigraphy is currently not routinely available for most veterinarians (Peterson, 2013).

Whether or not iatrogenic hypothyroidism should be treated immediately or monitored depends on the renal function of the cat. When bloodwork does not reveal azotemia, the iatrogenic hypothyroidism should not be treated within the first six months after ${ }^{131}$ I treatment. However, if the cat is azotemic, treatment with thyroid hormone supplementation has been shown to improve renal function and increase the median survival time in these cases (Williams et al., 2014; Vaske et al., 2015; Peterson et al, 2017). An algorithm with recommendations regarding diagnosis, monitoring and treatment of hyperthyroid cats treated with ${ }^{131} \mathrm{I}$ is presented in Figure 3.
Unfortunately, currently, there is no reliable test available that predicts post-treatment azotemia in hyperthyroid cats. Serum creatinine $(\mathrm{sCr})$ concentrations are influenced by body muscle mass, which is usually decreased in hyperthyroid cats. Increased glomerular filtration rate (GFR) in hyperthyroid cats also leads to decreased $\mathrm{sCr}$ concentrations, which makes it a less optimal indicator for azotemia in these cats. Direct measurement of GFR is not frequently used in clinical settings because the process is time-demanding and potentially stressful for the cats. Serum symmetric dimethylarginine (SDMA), a byproduct of cellular protein metabolism, is not affected by these extrarenal factors and is therefore suspected to be a better biomarker for the detection of CKD. However, SDMA has a poor sensitivity (33\%) to diagnose early kidney disease in hyperthyroid cats (Peterson et al., 2018). In addition, Burresova et al. (2019) showed that cats treated with ${ }^{131}$ I show a poor correlation between SDMA and GFR.

One month post treatment, the cat in the present case already showed decreased TT4 concentrations with normal TSH concentrations. Treatment with Lthyroxine was not instituted at this point in time because 1 . only a short period had elapsed after treatment, which could reflect transient hypothyroidism; 2 . the kidney values remained within the reference interval; 3. no obvious clinical signs of hypothyroi- 
dism were observed and 4. TSH was not significantly increased.

One year post treatment, the patient was orally administered levothyroxine because of low serum fT4 concentrations, high serum TSH concentration, decreased thyroid visibility on thyroid scintigraphy, increasing kidney values (still within reference interval) and hypertension. At that time point, the cat became lethargic and had mild weight loss (but still a normal body condition score). Lethargy is a common clinical sign in cats with iatrogenic hypothyroidism. Weight loss, however, is unfrequently noticed in hypothyroid cats (Peterson, 2013). Further diagnostic tests were performed in the cat of the present case, including an extensive blood examination, urinalysis, abdominal ultrasound and echocardiography, which didn't reveal other abnormalities besides the mild increase in renal values, proteinuria and hypertension. For this reason, it was recommended to closely follow-up these renal parameters after the initiation of treatment with oral levothyroxine. In addition, the cat showed significant clinical improvement once this treatment was started.

In the present case, the thyroxine and TSH concentrations had not been monitored for six months after treatment, due to a loss of follow-up at that time; otherwise, treatment in this cat might have been initiated sooner.

After starting levothyroxine supplementation, improvement of the mental status and activity level should be noticed within a couple of days. After a couple of weeks, weight loss might be noticed and the hair coat should improve within the first few months. Blood examination should be performed four to eight weeks after the start of the treatment and should include serum urea, creatinine, T4 (TT4 or fT4) and TSH concentrations. Post-treatment blood samples should be collected approximately four hours after the levothyroxine supplementation in order to be able to measure T4 peak serum concentrations. Ideally, T4 concentrations rise and TSH concentrations drop into the reference interval. If these values are not reached, dose adjustment is advised (Daminet, 2016). In the present case, the TT4 concentration increased into the reference interval, renal variables decreased and the cat was clinically stable, hence no dose adjustment was instituted. The serum SDMA concentration in the present case was higher than one year after the ${ }^{131} \mathrm{I}$ treatment. There are currently no studies available in which the correlation of SSDMA and GFR has been examined in iatrogenic hypothyroid cats treated with levothyroxine, which makes the interpretation of this result challenging.

It is important to note that also medical treatment with methimazole can cause iatrogenic hypothyroidism in cats. Between $20-40 \%$ of cats treated with methimazole become iatrogenic hypothyroid (Aldridge et al., 2015). Many of these cats have TSH concentrations within the reference interval during the first three months of treatment, but iatrogenic hypothyroidism often occurs at a later stage of treatment (Aldridge et al., 2015). Just as in cats treated with ${ }^{131}$ I, TT4 or fT4 values should always be interpreted in combination with TSH concentrations. This emphasizes the importance of closely monitoring these cats, including regular bloodwork to check T4 and TSH concentrations in cats treated with methimazole. When low/normal low T4 concentrations and high TSH concentrations are found, the methimazole dose should be lowered, even in the absence of clear clinical signs (Aldridge et al., 2015).

\section{CONCLUSION}

Diagnosing, monitoring and treating iatrogenic hypothyroidism in cats can be challenging. Making the decision to start thyroid hormone supplementation can be difficult as iatrogenic hypothyroidism can be transient. Currently, thyroid hormone supplementation is always recommended in azotemic cats as iatrogenic hypothyroidism could negatively influence survival rates in these cats (Figure 3 ).

\section{REFERENCES}

Aldridge C., Behrend E.N., Martin L.G., Refsal K., Kemppainen R.J., Lee H.P., Chciuk K. (2015). Evaluation of thyroid stimulating hormone, total thyroxine, and free thyroxine concentrations in hyperthyroid cats receiving methimazole treatment. Journal of Veterinary Internal Medicine 29(3), 862-868.

Boag A.K., Neiger R., Slater L., Stevens K.B., Haller M., Church D.B. (2007). Changes in the glomerular filtration rate of 27 cats with hyperthyroidism after treatment with radioactive iodine. Veterinary Record 161, 711-715.

Boretti F.S., Sieber-Ruckstuhl N.S., Lahula P., Reusch C.E. (2005). Thyroid enlargement and its relationship to serum $\mathrm{T}_{4}$ status in clinically suspected hyperthyroid cats. Journal of Veterinary Internal Medicine 19(6), 935.

Buresova E., Stock E., Paepe D., Stammeleer L., Vandermeulen E., Smets P., Daminet, S. (2019). Assessment of symmetric dimethylarginine as a biomarker of renal function in hyperthyroid cats treated with radioiodine. Journal of Veterinary Internal Medicine 33(2), 516-522.

Carney H.C., Ward C.R., Bailey S.J., Bruyette D., Dennis S., Ferguson D., Hinc A., Rucinsky A.R. (2016). 2016 AAFP Guidelines for the management of feline hyperthyroidism. Journal of Feline Medicine and Surgery 18(5), 400-416.

Daminet S. (2017) Feline hypothyroidism. In: Ettinger S.J., Feldman E.C., Côté E. (editors). Textbook of Veterinary Internal Medicine. Eighth edition edition, pp 1743-1747.

Daminet S. (2019). Treatment of hyperthyroidism: antithyroid drugs. In: Feldman E.C., Fracassi F., Peterson M.E. (editors). Feline Endocrinology. pp 198-209.

Daminet S., Hill K. (2017). Feline hyperthyroidism. In: W.D. Gram, R.J. Milner, R. Lobetti (editors). Chronic Disease Management for Small Animals, pp. 153-156.

Daminet S., Kooistra H.S., Fracassi F., Graham P.A., Hibbert A., Lloret A., Mooney C.T., Neiger R., Rosenberg 
D., Syme H.M., Villard I., Williams G. (2014). Best practice for the pharmacological management of hyperthyroid cats with antithyroid drugs. Journal of Small Animal Practice 55(1), 4-13.

Gunn-Moore D. (2005). Feline endocrinopathies. Veterinary Clinics of North America: Small Animal Clinics 35, 171-210.

Henrikson T.D., Armbrust L.J., Hoskinson J.J., Milliken G.A., Wedekind K.J., Kirk C.A., Nachreiner R.F. (2005). Thyroid to salivary ratios determined by technetium $99 \mathrm{~m}$ pertechnetate imaging in thirty-two euthyroid cats. Veterinary Radiology \& Ultrasound 46(6), 521-523.

Lucy J.M., Peterson M.E., Randolph J.F., Scrivani P.V., Rishniw M., Davignon D.L., Thompson M.S., Scarlett J.M. (2017). Efficacy of low-dose (2 millicurie) versus standard-dose (4 millicurie) radioiodine treatment for cats with mild-to-moderate hyperthyroidism. Journal of Veterinary Internal Medicine 31(2), 326-334.

McLean J.L., Lobetti R.G., Schoeman J.P. (2014). Worldwide prevalence and risk factors for feline hyperthyroidism: A review. Journal of the South African Veterinary Association, 85(1), 1-6.

Meric S.M., Rubin S.I. (1990). Serum thyroxine concentrations following fixed-dose radioactive iodine treatment in hyperthyroid cats: 62 cases (1986-1989). Journal of the American Veterinary Medical Association, 197(5), 621-623.

Mooney C.T. (2002). Pathogenesis of feline hyperthyroidism. Journal of Feline Medicine and Surgery 4(3), 167169.

Naan E.C., Kirpensteijn J., Kooistra H.S., Peeters M.E. (2006). Results of thyroidectomy in 101 cats with hyperthyroidism. Veterinary Surgery 35(3), 287-293.

Nykamp S.G., Dykes N.L., Zarfoss M.K., Scarlett J. M. (2005). Association of the risk of development of hypothyroidism after iodine 131 treatment with the pretreatment pattern of sodium pertechnetate Tc $99 \mathrm{~m}$ uptake in the thyroid gland in cats with hyperthyroidism: 165 cases (1990-2002). Journal of the American Veterinary Medical Association 226(10), 1671-1675.

Paepe D., Smets P., van Hoek I., Saunders J., Duchateau L., Daminet S. (2008). Within-and between-examiner agreement for two thyroid palpation techniques in healthy and hyperthyroid cats. Journal of feline medicine and surgery 10(6), 558-565.

Peterson M.E. (2013). Diagnostic testing for feline thyroid disease: hypothyroidism. Compendium: Continuing Education for Veterinarians 35, E1-E6.

Peterson M.E. (2016). Diagnosis and management of iatrogenic hypothyroidism. In: Little S. E. (editor). August's Consultations in Feline Internal Medicine. Elsevier, St. Louis, MO, USA. pp 260-269.

Peterson M.E., Broome M.R. (2015). Thyroid scintigraphy findings in 2096 cats with hyperthyroidism. Veterinary Radiology \& Ultrasound 56(1), 84-95.

Peterson M.E., Melian C., Nichols R. (2001). Measurement of serum concentrations of free thyroxine, total thyroxine, and total triiodothyronine in cats with hyperthyroidism and cats with nonthyroidal disease. Journal of the
American Veterinary Medical Association 218(4), 529536.

Peterson M.E., Nichols R., Rishniw M. (2017). Serum thyroxine and thyroid stimulating hormone concentration in hyperthyroid cats that develop azotemia after radioiodine therapy. Journal of Small Animal Practice 58(9), 519530.

Peterson, M. E., Varela, F. V., Rishniw, M., Polzin, D. J. (2018). Evaluation of serum symmetric dimethylarginine concentration as a marker for masked chronic kidney disease in cats with hyperthyroidism. Journal of Veterinary Internal Medicine 32(1), 295-304.

Peterson M.E., Ward C.R. (2007). Etiopathologic findings of hyperthyroidism in cats. Veterinary Clinics of North America: Small Animal Practice 37, 63-645.

Roover K.D., Duchateau L., Carmichael,N., Van Geffen C., Daminet S. (2006). Effect of storage of reconstituted recombinant human thyroid-stimulating hormone (rhTSH) on thyroid-stimulating hormone (TSH) response testing in euthyroid dogs. Journal of Veterinary Internal Medicine 20(4), 812-817.

Stammeleer L., Buresova E., Stock E., Vandermeulen E., Duchateau L., Daminet S. (2019). Determination of thyroid function in 131I treated hyperthyroid cats: serum thyroid variables compared to scintigraphy. Journal of Veterinary Internal Medicine 33(5), 2449-2450.

Stammeleer L., Feenstra L., Buresova E., Stock E., Vandermeulen E., Duchateau L., Van De Maele I., Daminet S. (2018). Evaluation of free T4 (fT4) measurement after equilibrium dialysis (FT4CEIA) in hyperthyroid cats before and after treatment with radioiodine $\left({ }^{131} \mathrm{I}\right)$. Journal of Veterinary Internal Medicine 33(2), 1079.

Vaske H.H., Schermerhorn T., Grauer G.F. (2015). Effects of feline hyperthyroidism on kidney function: a review. Journal of Feline Medicine and Surgery 18(2), 55-59.

Volckaert V., Vandermeulen E., Daminet S., Saunders J.H., Peremans K. (2016). Scintigraphic diagnosis and radioiodine treatment. Vlaams Diergeneeskundig Tijdschrift 85(5), 265-273.

Wakeling J. (2010). Use of thyroid stimulating hormone (TSH) in cats. The Canadian Veterinary Journal 51(1), 33-34.

Williams T.L., Elliott J., Syme H.M. (2010). Association of iatrogenic hypothyroidism with azotemia and reduced survival time in cats treated for hyperthyroidism. Journal of Veterinary Internal Medicine 24, 1086-1092.

Williams T.L., Elliott J., Syme H.M. (2014). Effect on renal function of restoration of euthyroidism in hyperthyroid cats with iatrogenic hypothyroidism. Journal of Veterinary Internal Medicine 28(4), 1251-1255.

\section{@creative}

C 2020 by the authors. Licensee Vlaams Diergeneeskundig Tijdschrift, Ghent University, Belgium. This article is an open access article distributed under the terms and conditions of the Creative Commons Attribution (CC BY) license (http://creativecommons.org/licenses/by/4.0/). 